\title{
1 \\ Controlled Synthesis of Polyenes by Catalytic Methods
}

Progress report for the period 12/1/89 - 11/30/92

and

DOE/ER/13564--11

DE92 015286

Publications appearing during grant period (page 12)

by

\author{
Richard R. Schrock \\ Department of Chemistry 6-331 \\ Massachusetts Institute of Technology \\ Cambridge, Massachusetts 02139
}

Several years ago we discovered how to prepare well-characterized alkylidene complexes of tungsten and molybdenum, and more importantly, how to control their activity for olefin metathesis reactions. ${ }^{1}$ This led to their development as catalysts for the controlled (living) ringopening of cyclic olefins, ${ }^{2}$ and created an opportunity in the area of polymerization of acetylenes to polyenes, since one of the proposed methods of polymerizing acetylenes involves an alkylidene catalyst as the active species. $3,4,5$ The systematic synthesis of polyenes became the subject of DOE research.

(1) (a) Schrock, R. R. J. Organometal. Chem. 1986, 300, 249. (b) Schaverien, C. J.; Dewan, J. C.; Schrock, R. R. J. Am. Chem. Soc. 1986, 108, 2771. (c) Murdzek, J. S.; Schrock, R. R. Organometallics 1987, 6, 1373. (d) Schrock, R. R.; DePue, R.; Feldman, J.; Schaverien, C. J.; Dewan, J. C.; Liu, A. H. J. Am. Chem. Soc. $1988,110,1423$.

(2) Schrock, R. R. Acc. Chem. Res. 1990, 23, 158.

(3) (a) Masuda, T.; Higashimura, T. Adv. Polym. Sci. 1986, 81, 121. (b) Katz, T. J.; Lee, S. J. J. Am. Chem. Soc. 1980, 102, 422. (c) Han, C.-C.; Katz, T. J. Organometallics 1985, 4, 2186. (d) Katz, T. J.; Hacker, S. M.; Kendrick, R. D.; Yannoni, C. S. J. Am. Chem. Soc. 1985, 107, 2182. (e) Katz, T. J.; Sivavec, T. M. J. Am. Chem. Soc. 1985, 107, 737.

(4) Wallace, K. C.; Liu, A. H.; Davis, W. M.; Schrock, R. R. Organometallics 1989, 8, 644.

(5) Katz, T. J.; Lee, S. J. J. Am. Chem. Soc. 1980, 102, 422. (b) Han, C.-C.; Katz, T. J. Organometallics 1985, 4, 2186. (c) Katz, T. J.; Hacker, S. M.; Kendrick, R. D.; Yannoni, C. S. J. Am. Chem. Soc. 1985, 107, 2182. (d) Katz, T. J.; Sivavec, T. M. J. Am. Chem. Soc. 1985, 107, 737. 


\section{DISCLAIMER}

This report was prepared as an account of work sponsored by an agency of the United States Government. Neither the United States Government nor any agency Thereof, nor any of their employees, makes any warranty, express or implied, or assumes any legal liability or responsibility for the accuracy, completeness, or usefulness of any information, apparatus, product, or process disclosed, or represents that its use would not infringe privately owned rights. Reference herein to any specific commercial product, process, or service by trade name, trademark, manufacturer, or otherwise does not necessarily constitute or imply its endorsement, recommendation, or favoring by the United States Government or any agency thereof. The views and opinions of authors expressed herein do not necessarily state or reflect those of the United States Government or any agency thereof. 


\section{DISCLAIMER}

Portions of this document may be illegible in electronic image products. Images are produced from the best available original document. 
This project began when we showed that the polymerization of $\operatorname{TCDT}^{6}(3,4$ bistrifluoromethyltricyclo[4.2.2.02,5]deca-3,7,9-triene) could be controlled by well-characterized tungsten catalysts ${ }^{7}$ to give a series of "odd" polyenes containing $2 x+1$ double bonds if pivaldehyde is employed in the Wittig-like capping reaction, or a series of "even" polyenes containing $2 \mathrm{x}+2$ double bonds if 4,4-dimethyl-trans-2-pentenal is employed in the capping reaction (equation 1).

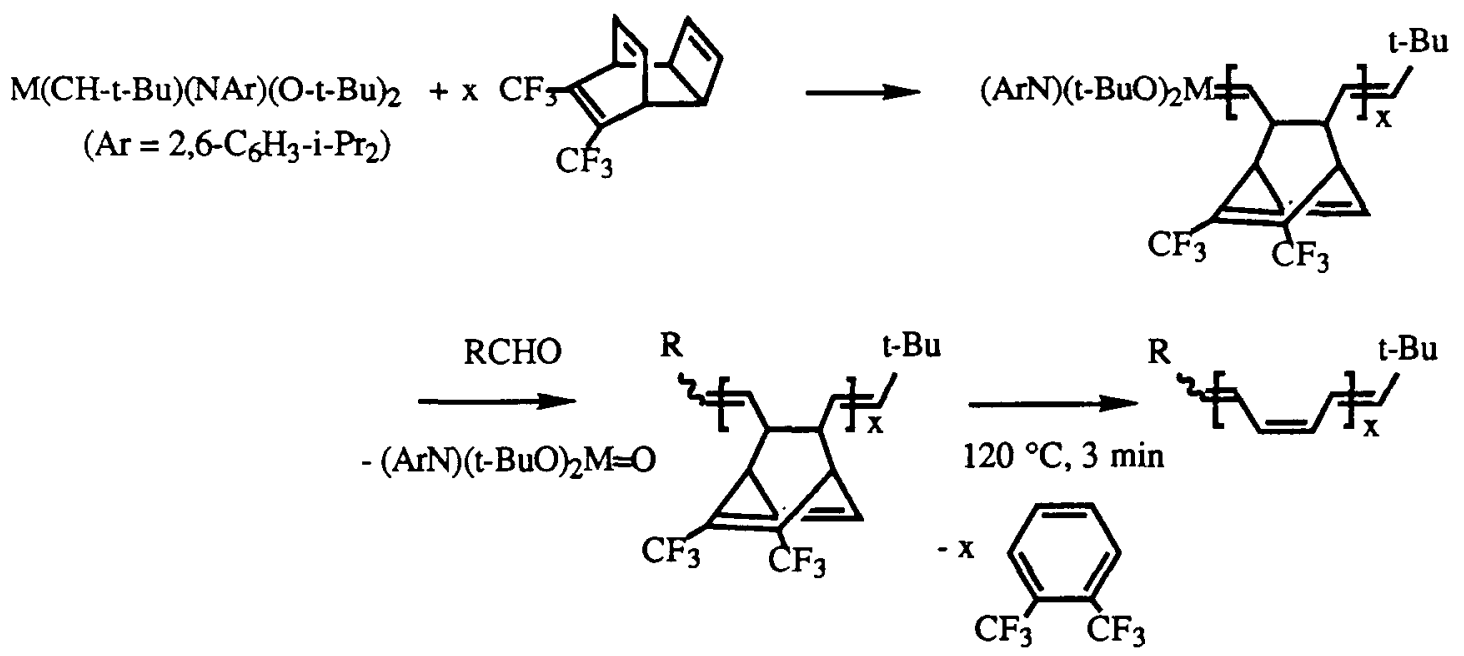

$\mathrm{W}(\mathrm{CH}-\mathrm{t}-\mathrm{Bu})(\mathrm{NAr})(\mathrm{O}-\mathrm{t}-\mathrm{Bu})_{2}\left(\mathrm{Ar}=2,6-\mathrm{C}_{6} \mathrm{H}_{3}-\mathrm{i}-\mathrm{Pr}_{2}\right)$ was used in the first study, in large part because only the tungsten catalyst was available at the time. In the past grant period we showed that the analogous molybdenum catalyst can be used instead of the tungsten catalyst. ${ }^{8}$ The molybdenum catalyst, which now is the easiest to prepare in large quantities, gives higher yields of polyene, but the reaction still is exceedingly finely balanced. The biggest problem appears to be opening of the other disubstituted double bond to yield a cross-linked system in which conjugation is disrupted. This problem is especially severe when the unsubstituted monomer is employed. The steric role of the $\mathrm{CF}_{3}$ groups therefore is an important one. They may also have an important electronic role, i.e., they deactivate the living alkylidene to a significant extent, an effect that was found for ring-opening of 2,3-bistrifluoromethylnorbornadiene, ${ }^{9}$ and one that limits secondary

(6) (a) Bott, D. C.; Brown, C. S.; Edwards, J. H.; Feast, W. J.; Parker D.; Winter, J. N. Mol. Cryst. Liq. Cryst. 1985, 117, 9. (b) Edwards, J. H.; Feast, W. J.; Bott, D. C. Polymer 1984, 25, 395. (c) Feast, W. J.; Winter, J. N. J. Chem. Soc., Chem. Commun. 1985, 202.

(7) Knoll, K.; Schrock, R. R. J. Am. Chem. Soc. 1989, 111, 7989.

(8) Park, L. Y.; Stieglitz, S. G.; Crowe, W. M.; Schrock, R. R. Macromolecules 1991, 24, 3489.

(9) Bazan, G.; Khosravi, E.; Schrock, R. R.; Feast, W. J.; Gibson, V. C.; O'Regan, M. B.; Thomas, J. K.; Davis, W. M. J. Am. Chem. Soc. 1990, 112, 8378. 
- metathesis to some extent.

Some optical and electrochemical properties of polyenes prepared in this fashion were examined in collaborations. Chance and Silbey ${ }^{10,11}$ determined the dependence of linear optical properties on chain length, while Bally prepared and examined radical cations of pure discrete polyenes. ${ }^{12}$ Polyacetylene films also were deposited on microelectrodes and were shown to have a finite potential window of high conductivity. ${ }^{13}$ A full paper on this work has now been submitted. In this paper we report that approximately 20 nominal conjugated double bonds are required in order to observe "classical" conductivity, but that conductivity maximizes when approximately 50 nominal conjugated double bonds are present. No solution electrochemical studies were possible for di-t-butyl-capped polyene samples owing to low solubility.

PolyTCDT/polynorbornene diblock copolymers can be prepared and the polyTCDT block converted to a polyene block. The resulting diblocks proved to be much more soluble in solvents such as THF than the analogous di-t-butyl-capped polyenes. In fact, we could achieve a concentration of polyene approximately three orders of magnitude greater than was possible for the analogous di-t-butyl-capped polyenes. Higher solubility proved to be a key to obtaining good values of the molecular third order hyperpolarizability $(\gamma)$ via EFISH methods in collaboration with Dr. Joseph Zyss at the Centre National d'Etude des Télécommunications in Bagneux, France, one of the recognized world's experts in NLO measurements. (A full paper has been submitted). They found that $\gamma_{N}(-2 \omega ; \omega, 0)$ varied with the chain length to the 3.6 power, while $\gamma_{N}(0)$ varied with the chain length to the 3.2 power. These correlations are only possible if polyenes have either a fixed or a well-defined and known chain length. Many analogous studies are anticipated and are outlined in the proposal proper.

A more direct approach to polyenes by the direct polymerization of acetylenes (equation 2)

(10) Schaffer, H. E.; Chance, R. R.; Knoll, K.; Schrock, R. R.; Silbey, R. J. Conjugated Polymeric Materials: Opportunities in Electronics, Optoelectronics, and Molecular Electronics, J. Bredas and R. Chance, Ed., Kluwer, 1990 , p. 365.

(11) Schaffer, H. E.; Chance, R. R.; Silbey, R. J.; Knoll, K.; Schrock, R. R. J. Chem. Phys. $1991,94,4161$.

(12) Bally, T.; Roth, K.; Tang, W.; Schrock, R. R.; Knoil, K.; Park, L. Y. J. Am. Chem. Soc. 1992, 114, 2440.

(13) Ofer, D.; Park, L. Y.; Schrock, R. R.; Wrighton, M. S. Chem. Mat. 1991, 3, 573. 
was also one of the achievements of the last grant period. We were able to show that polymerization of acetylene itself can be controlled with a well-characterized alkylidene catalyst, ${ }^{14}$ but only if a base such as quinuclidine is present in order to slow down the rate of propagation relative to initiation. (Quinuclidine may also stabilize vinylalkylidene intermediates formed in the reaction.) Unfortunately, "living polyenes" were no more stable than isolated polyenes, and so this approach again had its limitations. Direct polymerization of acetylene by Mo(CH-t$\mathrm{Bu})(\mathrm{NAr})(\mathrm{O}-\mathrm{t}-\mathrm{Bu})_{2}$ was more successful, but inherent polyene instability was still a problem. ${ }^{8}$

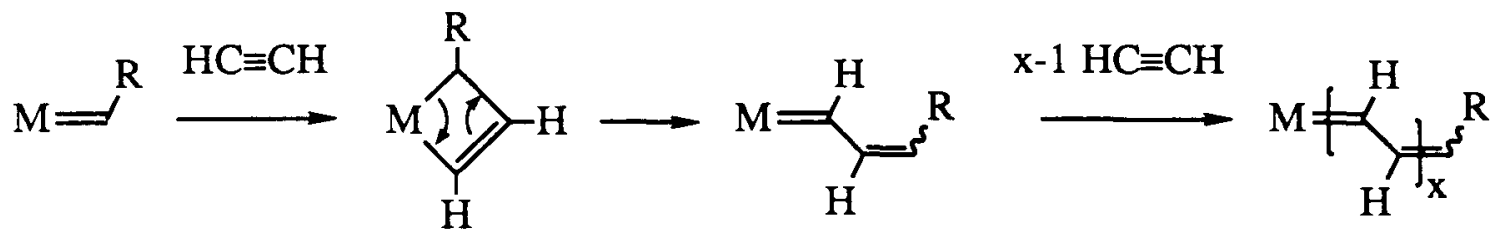

In order to obtain more accurate information concerning the dependence of $\gamma$ on chain length, we sought to prepare polyenes stoichiometrically. We found that it is possible to react a terminal diene with a neopentylidene complex, as shown in equation $3\left(\mathrm{OR}=\mathrm{OCMe}\left(\mathrm{CF}_{3}\right)_{2}, \mathrm{~S}_{2}=\right.$ dimethyoxyethane). Reactions analogous to that shown in equation 3 involving 0.5 equivalents of octatetraene, hexatriene, or divinylbenzene yield the telechelic complexes $\left[(\text { ether })(\mathrm{RO})_{2}(\mathrm{ArN}) \mathrm{Mo}=\mathrm{CH}-\mathrm{CH}=\mathrm{CH}\right]_{2}, \quad\left[(\text { ether })(\mathrm{RO})_{2}(\mathrm{ArN}) \mathrm{Mo}=\mathrm{CH}-\mathrm{CH}=\right]_{2}$, and $\left[(\text { dimethoxyethane })(\mathrm{RO})_{2}(\mathrm{ArN}) \mathrm{Mo}=\mathrm{CH}\right]_{2} \mathrm{C}_{6} \mathrm{H}_{4}$, respectively. These species can be obtained in crystalline form in high yield and react readily with aldehydes to give the expected product of a Wittig-like reaction. They also react with 4 equivalents of $t$-butoxide ion to give analogous $t$ butoxide complexes in situ, as judged by the successful synthesis of low polydispersity polyMTD with the expected molecular weight employing the generated t-butoxide complexes as initiators. Somewhat surprisingly, we also found that polyTCDT can be synthesized from one of the $\mathrm{OCMe}\left(\mathrm{CF}_{3}\right)_{2}$ telechelic initiators in dimethoxyethane. Therefore either $\mathrm{O}-\mathrm{t}-\mathrm{Bu}$ or $\mathrm{OCMe}\left(\mathrm{CF}_{3}\right)_{2}$ complexes now can be employed to make polyenes in living polymerizations in toluene or dme, respectively.

(14) Schlund, R.; Schrock, R. R.; Crowe, W. E. J. Am. Chem. Soc. 1989, 111, 8004. 


$$
\mathrm{Mo}(\mathrm{CH}-\mathrm{t}-\mathrm{Bu})(\mathrm{NAr})(\mathrm{OR})_{2} \underset{+\mathrm{S}-(\mathrm{t}-\mathrm{Bu}) \mathrm{CH}=\mathrm{CH}_{2}}{\stackrel{+}{\longrightarrow}} \mathrm{Mo}(\mathrm{CHCH}=\mathrm{CHMe})(\mathrm{NAr})(\mathrm{OR})_{2}(\mathrm{~S})_{2}
$$

Another important finding is that the unsaturated monoaldehydes, 8,8-dimethyl-2,4,6nonatriene-1-al and 10,10-dimethyl-2,4,6,8-undecatetraene-1-al, can be prepared in good yield by treating the corresponding unsaturated $\alpha, \omega$-dialdehydes with 0.5 equiv of $\mathrm{Mo}(\mathrm{CH}-\mathrm{t}-\mathrm{Bu})(\mathrm{NAr})(\mathrm{O}-$ $\mathrm{t}-\mathrm{Bu})_{2}$ (equation $4 ; \mathrm{x}=2$ or 3 ). Although some di-t-butyl-capped polyenes are formed and some $\mathrm{OHC}(\mathrm{CH}=\mathrm{CH})_{\mathrm{x}} \mathrm{CHO}+\mathrm{Mo}(\mathrm{CH}-\mathrm{t}-\mathrm{Bu})(\mathrm{NAr})(\mathrm{O}-\mathrm{t}-\mathrm{Bu})_{2} \longrightarrow$
$\mathrm{t}-\mathrm{Bu}(\mathrm{CH}=\mathrm{CH})_{\mathrm{x}+1} \mathrm{CHO}+\mathrm{Mo}(\mathrm{O})(\mathrm{NAr})(\mathrm{O}-\mathrm{t}-\mathrm{Bu})_{2}$

dialdehyde therefore left unreacted, the desired monoaldehydes are easily purified by chromatography and can be obtained in $-75 \%$ isolated yield. By variations of reactions analogous to those shown in equations 3 and 4 we have been able to prepare the entire series of all trans di-tbutyl capped polyenes containing up to 12 double bonds as shown in Table I. The reactions occur cleanly and quantitatively, the only products being the desired polyenes and $\mathrm{Mo}(\mathrm{O})(\mathrm{NAr})(\mathrm{O}-\mathrm{t}$ $\mathrm{Bu})_{2}$, and typically are complete at room temperature in less than one hour. A full paper on this work is in preparation. We are now in the process of attempting to extend this chemistry to the synthesis of polynorbornenes that contain a polyene sequence of a specific length in order to determine more accurately (as a result of higher solubility) the dependence of the third order hyperpolarizability on chain length.

Polymerization of disubstituted alkynes is relatively uninteresting, as far as conductivity or NLO properties are concerned, since the chains are twisted (not conjugated). Monosubstituted alkynes might be able to form conjugated polyenes, if chain growth is regiospecific, as shown in equation 5 , even though the evidence available in the literature would suggest that $\pi$ conjugation in such polymers also is minimal. ${ }^{15}$ However, if the acetylene adds as shown in equation 6 ,

(15) (a) Masuda, T.; Mishima, K.; Fujimori, J.-I.; Nishida, M.; Muramatsu, H.; Higashimura, T. Macromolecules 1992, 25, 1401. (b) Yoshimura, T.; Masuda, T.; Higashimura, T.; Okuhara, K.; Ueda, T. Macromolecules 1991, 23, 6053. (c) Masuda, T.; Hamano, T.; Tsuchihara, K. a., T. Macromolecules 1990, 23, 1374. (d) Masuda, T.; Yoishimura, T.; Higashimura, T. Macromolecules 1989, 22, 3804. (e) Fontanille, M.; Lucas, C.; Soum, A. Makromol. Chem. - Macromol. Chem. Phys. 1992, 193, 411. (f) Masuda, T.; Mishima, K.; Fujimori, J.-I.; Nishida, M.; Muramatsu, H.; Higashimura, T. Macromolecules 1992, 25, 1401. 
Table I. Synthesis of Polyenes Employing Wittig-like Reactions.

\begin{tabular}{|c|c|c|}
\hline Reagent & Aldehyde & $(\mathrm{t}-\mathrm{Bu})(\mathrm{CH}=\mathrm{CH})_{\mathrm{n}}(\mathrm{t}-\mathrm{Bu})($ n-ene $)$ \\
\hline $\mathrm{Mo}=\mathrm{CH}(\mathrm{t}-\mathrm{Bu})$ & $\mathrm{t}-\mathrm{BuCHO}$ & 1-ene \\
\hline $\mathrm{Mo}=\mathrm{CH}(\mathrm{t}-\mathrm{Bu})$ & $\mathrm{t}-\mathrm{BuCH}=\mathrm{CHCHO}$ & 2-ene \\
\hline $\mathrm{Mo}=\mathrm{CHCH}=\mathrm{CH}(\mathrm{t}-\mathrm{Bu})$ & $\mathrm{t}-\mathrm{BuCH}=\mathrm{CHCHO}$ & 3-ene \\
\hline $\mathrm{Mo}=\mathrm{CH}(\mathrm{t}-\mathrm{Bu})(2$ equiv $)$ & $\mathrm{OHC}(\mathrm{CH}=\mathrm{CH})_{2} \mathrm{CHO}$ & 4-ene \\
\hline $\mathrm{Mo}=\mathrm{CH}(\mathrm{t}-\mathrm{Bu})(2$ equiv $)$ & $\mathrm{OHC}(\mathrm{CH}=\mathrm{CH})_{3} \mathrm{CHO}$ & 5 -ene \\
\hline $\mathrm{Mo}=\mathrm{CHCH}=\mathrm{CH}(\mathrm{t}-\mathrm{Bu})(2$ equiv $)$ & $\mathrm{OHC}(\mathrm{CH}=\mathrm{CH})_{2} \mathrm{CHO}$ & 6-ene \\
\hline $\mathrm{Mo}=\mathrm{CHCH}=\mathrm{CH}(\mathrm{t}-\mathrm{Bu})(2$ equiv $)$ & $\mathrm{OHC}(\mathrm{CH}=\mathrm{CH})_{3} \mathrm{CHO}$ & 7-ene \\
\hline $\mathrm{Mo}=\mathrm{CH}(\mathrm{CH}=\mathrm{CH})_{3}(\mathrm{t}-\mathrm{Bu})$ & $\mathrm{t}-\mathrm{Bu}(\mathrm{CH}=\mathrm{CH})_{4} \mathrm{CHO}$ & 8-ene \\
\hline $\mathrm{Mo}=\mathrm{CHCH}=\mathrm{CHCH}=\mathrm{Mo}$ & $\mathrm{t}-\mathrm{Bu}(\mathrm{CH}=\mathrm{CH})_{3} \mathrm{CHO}^{\mathrm{a}}$ & 9-ene \\
\hline $\mathrm{Mo}=\mathrm{CH}(\mathrm{CH}=\mathrm{CH})_{2} \mathrm{CH}=\mathrm{Mo}$ & $\mathrm{t}-\mathrm{Bu}(\mathrm{CH}=\mathrm{CH})_{3} \mathrm{CHO}^{\mathrm{a}}$ & 10-ene \\
\hline $\mathrm{Mo}=\mathrm{CHCH}=\mathrm{CHCH}=\mathrm{Mo}$ & $\mathrm{t}-\mathrm{Bu}(\mathrm{CH}=\mathrm{CH})_{4} \mathrm{CHO}^{\mathrm{a}}$ & 11-ene \\
\hline $\mathrm{Mo}=\mathrm{CH}(\mathrm{CH}=\mathrm{CH})_{2} \mathrm{CH}=\mathrm{Mo}$ & $\mathrm{t}-\mathrm{Bu}(\mathrm{CH}=\mathrm{CH})_{4} \mathrm{CHO}^{\mathrm{a}}$ & 12-ene \\
\hline
\end{tabular}<smiles>[R]C(=[W])C([R])=CP</smiles>

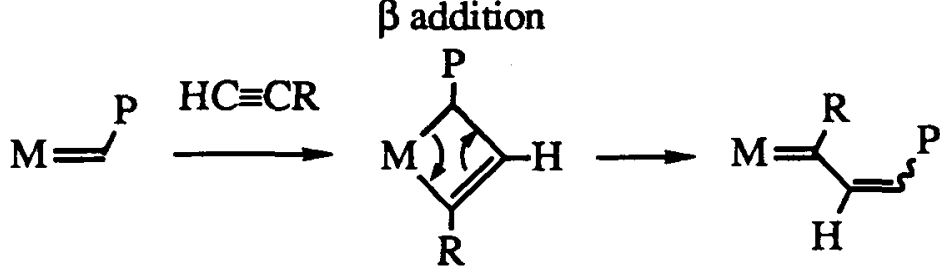

polymerization would effectively cease as a result of the relatively low reactivity of a disubstituted alkylidene complex. We believe this to be a limitation in all such reactions we have tried over the last 3 years. For example, 50 equivalents of phenylacetylene can be polymerized by W(CH-t- 
- $\mathrm{Bu})(\mathrm{NAr})(\mathrm{O}-\mathrm{t}-\mathrm{Bu})_{2}$ in the presence of a base such as paradimethylaminopyridine to give polymers with relatively low polydispersities ( 1.2), but polymerization activity then ceases. Polymerization of acetylenes such as 1-octyne are somewhat more successful (100 equiv can be polymerized before deactivation). There is some evidence that regiochemistry might be controlled to some extent electronically. For example, alkoxy alkynes appear to be polymerized relatively regiospecifically, but unfortunately the resulting alkoxy-substituted polyenes are not very stable thermally, or toward air.

The most important result of the past grant period is the finding that dipropargyl derivatives ( $\mathrm{HC} \equiv \mathrm{CCH}_{2} \mathrm{XCH}_{2} \mathrm{C} \equiv \mathrm{CH} ; \mathrm{X}=\mathrm{CH}_{2}, \mathrm{C}\left(\mathrm{CO}_{2} \mathrm{R}\right)_{2}, \mathrm{SiR}_{2}$, etc.), which have been reported to be cyclopolymerized by various classical catalysts by as yet unknown mechanisms, ${ }^{16}$ are polymerized by $\mathrm{Mo}(\mathrm{CH}-\mathrm{t}-\mathrm{Bu})(\mathrm{NAr})\left[\mathrm{OCMe}\left(\mathrm{CF}_{3}\right)_{2}\right]_{2}$ in dimethoxyethane. We speculate that intramolecular formation of a five-membered ring in the product of $\alpha$ addition (Scheme $\mathrm{I}$ ) is fast enough to yield another terminal alkylidene on the time scale of the polymerization reaction, while a six-membered ring is formed in a reaction involving a more reactive terminal alkylidene. Either intermediate alkylidene, but most likely the terminal alkylidene, could react with additional monomer to lead to growth of a chain having "dangling" triple bonds that eventually could be employed to form crosslinks (e.g., equation 7).
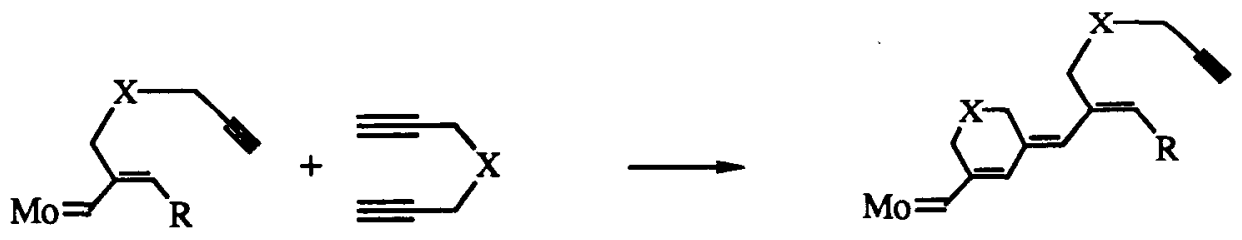

(16) (a) Cho, O. K.; Kim, Y. H.; Choi, K. Y.; Choi, S. K. Macromolecules 1990, 23, 12. (b) Gibson, H. W.; Epstein, A. J.; Rommelmann, H.; Tanner, D. B.; Yang, X. Q.; Pochan, J. M. J. Phys., Colloq. 1983, C3, 651. (c) Han, S. H.; Kim, U. Y.; Kang, Y. S.; Choi, S. K. Macromolecules 1991, 24, 973. (d) Jang, M. S.; Kwon, S. K.; Choi, S. K. Macromolecules 1990, 23, 4135. (e) Jin, S. H.; Kim, S. H.; Cho, H. N.; Choi, S. K. Macromolecules 1991, 24, 6050. (f) Kim, Y. H.; Gal, Y. S.; Kim, U. Y.; Choi, S. K. Macromolecules 1988, 21, 1991. (g) Kim, Y. H.; Choi, K. Y.; Choi, S. K. J. Polym. Sci. C Polym. Letters 1989, 27, 443. (h) Ryoo, M. S.; Lee, W. C.; Choi, S. K. Macomolecules 1990, 23, 3029. (i) Stille, J. K.; Frey, D. A. J. Am. Chem. Soc. 1961, 83, 1697. 


\section{Scheme I}
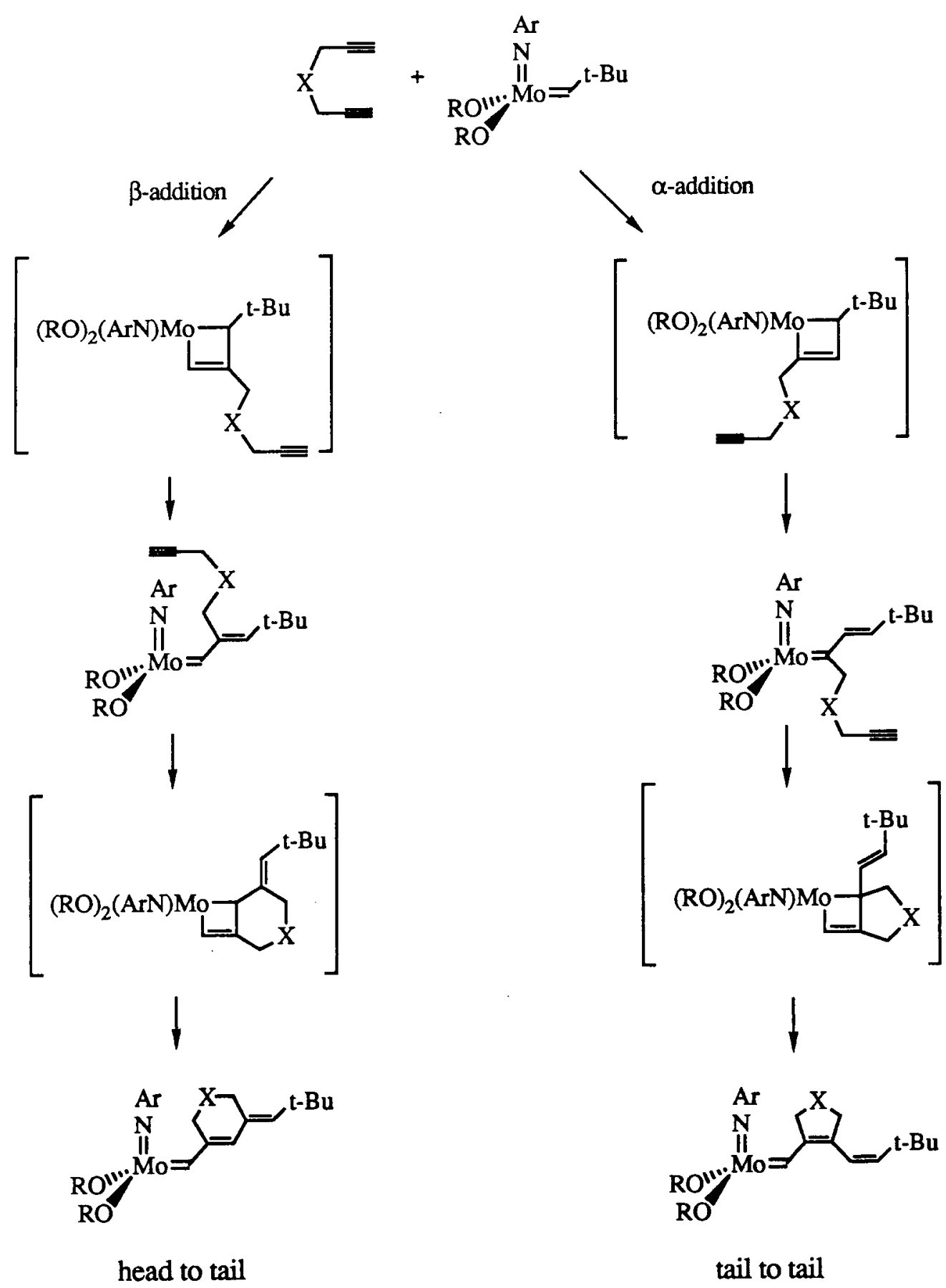
$\mathrm{Mo}(\mathrm{CH}-\mathrm{t}-\mathrm{Bu})(\mathrm{NAr})\left[\mathrm{OCMe}\left(\mathrm{CF}_{3}\right)_{2}\right]_{2}$ in dimethoxyethane will smoothly polymerize the diethylmalonate derivative $\left(\mathrm{X}=\mathrm{C}\left(\mathrm{CO}_{2} \mathrm{Et}\right)_{2}\right)$ in a living manner, as shown by observation of new $\mathrm{H}_{\alpha}$ resonances at 13.03 and $12.41 \mathrm{ppm}$ that are characteristic of $\alpha$ proton resonances in vinyl alkylidene complexes, the linear increase in molecular weight with monomer conversion, and the synthesis of narrow dispersity block copolymers containing MTD. No resonances in the range of 7.5 to $8.5 \mathrm{ppm}$ characteristic of $\beta$ protons in vinyl alkylidene complexes were observed, suggesting that no disubstituted alkylidene complexes were present. We tentatively assign the new $\mathrm{H}_{\alpha}$ resonances to complexes in which a five-membered ring or six-membered ring is attached to the alkylidene carbon atom. The absolute molecular weight of all polymers has been determined by on-line solution viscometry on the GPC effluent. Determination of the absolute molecular weight directly in this manner is possible for polymers that may be considered solvated "random coils", and is now routine in our laboratory.

Poly $_{\mathbf{n}}(1$ = dipropargyldiethylmalonate; Table II) is very soluble in DME, THF, acetone, toluene, dichloromethane, chloroform, and acetonitrile, but not pentane. Approximately 5\% of a polymer with double the expected molecular weight appears in poly $1_{80}$, which we ascribe to a small amount of cross-linking through "dangling" terminal triple bonds. No acetylenic C-H bonds were detected in a solution IR spectrum of poly $1_{80}$. The ${ }^{13} \mathrm{C}$ NMR spectrum of poly $1_{80}$ reveals two carbonyl carbon resonances, while the ${ }^{13} \mathrm{C}$ NMR spectrum of poly1 prepared using a $\mathrm{MoCl}_{5}$ catalyst, which is proposed to contain six-membered rings, revealed only one carbonyl carbon resonance. 15 Therefore we speculate that poly $\mathbf{1}_{\mathbf{n}}$ consists of a random distribution of fivemembered and six-membered rings formed through what is nominally tail-to-tail and head-to-tail cyclopolymerization of the two acetylenic bonds in the monomer, viz.
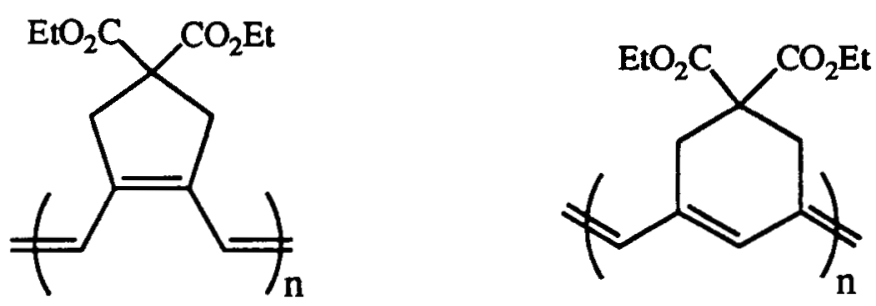
Table II. GPC, UV/Vis and yield data for poly $1_{\mathrm{n}}$ and poly $1_{20} 5_{200}$.

\begin{tabular}{|c|c|c|c|c|c|}
\hline Polymer & $\mathrm{M}_{\mathrm{n}}(\mathrm{g} / \mathrm{mol})^{\mathrm{a}}$ & $\begin{array}{c}\text { Degree of } \\
\text { Polymerization } \\
\end{array}$ & $\mathrm{M}_{\mathrm{w}} / \mathrm{M}_{\mathrm{n}}$ & $\lambda_{\max }(\mathrm{nm})^{\mathrm{b}}$ & Yield (\%) \\
\hline poly $1_{5}$ & 3640 & 15 & 1.21 & $514(504)$ & 98 \\
\hline $\operatorname{poly}_{10}$ & 6110 & 26 & 1.24 & $534(524)$ & 93 \\
\hline $\operatorname{poly}_{15}$ & $7520^{c}$ & 32 & 1.18 & $548(544)$ & 99 \\
\hline poly $1_{20}$ & 8790 & 37 & 1.25 & $548(544)$ & 100 \\
\hline poly $1_{40}$ & 11600 & 49 & 1.16 & $552(554)$ & 96 \\
\hline poly $1_{80}$ & 23200 & 98 & $1.23^{\mathrm{d}}$ & $556(574)$ & 97 \\
\hline poly $1_{20} \mathbf{5}_{200}$ & $48000^{e}$ & & 1.09 & $548(544)$ & 98 \\
\hline
\end{tabular}

a Determined by GPC on-line viscometry versus a polystyrene universal calibration curve (Viscotek). ${ }^{b}$ In THF or (in parentheses) in acetonitrile. ${ }^{c} M_{n}=7550( \pm 1200)$ was obtained by vapor pressure osmometry. $\mathrm{d}$ A small amount of double molecular weight material was observed by GPC. e $M_{n}$ vs. polystyrene.

UV/Vis data $\left(\lambda_{\max }\right)$ for poly1 prepared here (Table In) suggest that poly1 is indeed highly conjugated and reveal that $\lambda_{\max }$ continues to increase in a polymer containing approximately 100 double bonds. (In poly1 prepared using classical catalysts $\lambda_{\max } \approx 550 \mathrm{~nm} .{ }^{15}$ ) It is important to note that molecular NLO properties ( $\gamma$ in this case) may depend much more strongly on chain length than does $\lambda_{\max } \cdot{ }^{17}$

Other solvent and catalyst combinations yield poorer quality poly1. If THF is used as the solvent, the poly $1_{20}$ so obtained had a much larger polydispersity $(>2)$. Other catalysts such as $\mathrm{Mo}(\mathrm{CH}-\mathrm{t}-\mathrm{Bu})(\mathrm{NAr})\left[\mathrm{OCMe}_{2}\left(\mathrm{CF}_{3}\right)\right]_{2}$ and $\mathrm{W}(\mathrm{CH}-\mathrm{t}-\mathrm{Bu})(\mathrm{NAr})\left[\mathrm{OCMe}\left(\mathrm{CF}_{3}\right)_{2}\right]_{2}$ in DME yielded polymer mixtures that had broader polydispersities, contained higher molecular weight material,

(17) Conjugated Polymers; Brédas, J. L.; Silbey, R., Ed.; Kluwer. Boston, 1991. 
- and in the case of the tungsten system, produced low yields of polymer. Dimethoxyethane is likely to play a significant role in limiting secondary metathesis or termination reactions, as has been demonstrated for polymerizations by related catalysts in the presence of quinuclidine ${ }^{14}$ or phosphine. ${ }^{18}$

The fact that a catalyst and conditions have been found that effect the living polymerization of 1 suggests that it should be possible to polymerize other $\mathrm{HC} \equiv \mathrm{CCH}_{2} \mathrm{XCH}_{2} \mathrm{C} \equiv \mathrm{CH}$ derivatives in a living manner. These and related studies form the basis for a major part of the proposed research in the next three years.

(18) Wu, Z.; Wheeler, D. R.; Grubbs, R. H. J. Am. Chem. Soc. 1992, 114, 146. 
- Publications appearing since last competitive application (1989)

"Preparation of tert-Butyl-Capped Polyenes Containing up to 15 Double Bonds"

Knoll, K.; Schrock, R. R. J. Am. Chem. Soc. 1989, 111, 7989.

"Direct Polymerization of Acetylene to Give Living Polyenes"

Schlund, R.; Schrock, R. R.; Crowe, W. E. J. Am. Chem. Soc. 1989, 111, 8004.

"Linear Optical Properties of a Series of Oligomers of Polyacetylene"

Schaffer, H. E.; Chance, R. R.; Knoll, K.; Schrock, R. R.; Silbey, R. J. Conjugated

Polymeric Materials: Opportunities in Electronics, Optoelectronics, and Molecular Electronics, J. Bredas and R. Chance, Ed., Kluwer, 1990, p. 365.

"Conjugation Length Dependence of Raman Scattering in a Series of Linear Polyenes: Implications for Polyacetylene", Schaffer, H. E.; Chance, R. R.; Silbey, R. J.; Knoll, K.; Schrock, R. R. J. Chem. Phys. 1991, 94, 4161.

"The Preparation of Discrete Polyenes and Norbornene-Polyene Block Copolymers Using $\mathrm{Mo}(\mathrm{CH}-t$-Bu)(NAr)(O- $t$-Bu) 2 ", Park, L. Y.; Stieglitz, S. G.; Crowe, W. M.; Schrock, R. R. Macromolecules 1991, 24, 3489.

"Recent Advances in the Chemistry of "d0" Alkylidene and Metallacyclobutane Complexes" Feldman J.; Schrock, R. R. Prog. Inorg. Chem. 1991, 39, 1.

"Potential Dependence of the Conductivity of Polyacetylene: Finite Potential Windows of High Conductivity", Ofer, D.; Park, L. Y.; Schrock, R. R.; Wrighton, M. S. Chem. Mat. 1991, 3, 573.

"Stable Polarons in Polyacetylene Oligomers: Optical Spectra of Long Polyene Radical Cations" Bally, T.; Roth, K.; Tang, W.; Schrock, R. R.; Knoll, K.; Park, L. Y. J. Am. Chem. Soc. 1992, $114,2440$.

\section{Papers submitted or in press}

"The Preparation of a Series of Polyacetylene Samples by Means of Controlled Synthetic Method and the Effect of Chain Length on Conductivity"

Park, L. Y.; Ofer, D.; Schrock, R. R.; Wrighton, M. S., submitted.

"The Living Cyclopolymerization of Diethyl Dipropargylmalonate by $\mathrm{Mo}(\mathrm{CH}-\mathrm{t}-\mathrm{Bu})(\mathrm{NAr})$ -

$\left[\mathrm{OCMe}\left(\mathrm{CF}_{3}\right)_{2}\right]_{2}$ in Dimethoxyethane"

Fox, H. H.; Schrock, R. R., submitted.

"Nonlinear Optical Analysis of a Series of Triblock Copolymers Containing Model Polyenes; the Dependence of Hyperpolarizability on Conjugation Length"

Craig, G. S. W.; Cohen, R. E.; Schrock, R. R.; Puccetti, G.; Ledoux, I.; Zyss, J., submitted. 
UNIVERSITY OF CAMBRIDGE

DEPARTMENT OF PHYSICS

CAVENDISH LABORATORY

MADINGLEY ROAD

CAMBRIDGE CB3 OHE

from Dr. R. H. Friend

telephone: 0223-337218

e-mail: rhf10@phx.cam.ac.uk

$27 / 8 / 91$

Professor R. R. Schrock

Massachusetts Institute of Technology

Department of Chemistry, Rm 6-331

Cambridge MA 02139

USA

Dear Richard,

I am pleased to learn that you are keen to do the condensation polymerisations to form novel conjugated polymers. As we have discussed before, I would be very pleased to undertake to carry out measurements to characterise these materials. As you know we are able to carry out structural, optical and electrical measurements, and we would be very interested to be able to make comparison with the other conjugated polymers that we are studying here. We would be particularly interested in finding other polymers which could be used in some of the electronic and optoelectronic devices that we developing here, including MIS field-effect structures and also light-emitting diodes.

Yours sincerely,

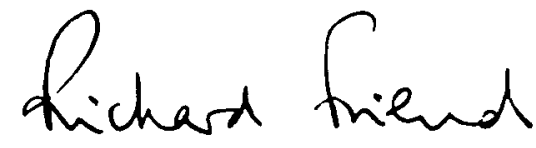




\section{Centre National d'Études des.Télécommunications}

Affaire suivie par M. J. ZYSS

Bagneux, le

Téléphone: (33.1) 42.31.73.14

Fax : (33.1) 42.53 .49 .30

Ref. : $\quad 225 / P \mathrm{MM} / \mathrm{EQM} / \mathrm{JZ}$

\section{Professor R. SCHROCK Department of Chemistry MIT \\ 77 Massachusetus Avenue \\ CAMBR IDGE, MA $(12139$ \\ U.S.A.}

\section{Doar Dick,}

I am glad to confinm that 1 look forward to the continuation and extension of our ongoing collatoration. Following successful mon-resonnant third hatmonic generation in your symmetric polynorbomene-polyene oligomers, we were atble to establish an exponemtial scaling law for the chainlength dependance of $\gamma$ up to $13 \mathrm{C}$-C double bonds in different isonners. It is now extremely worthwhile to extend this investigation to longer conjugation lengths based on the soluble polyacetylenes resulting from living cyclopolymerization that you have just made available to us. The possibility to explore compounds with chainlengil up to $N=150$ double bonds should pemit to observe the saturation of $\gamma$ with respect $10 \mathrm{~N}$. You may want to know that we are currently upgrading our set-up which should soon be able to deliver picosecond and subpicosecond pulses tunable through the visible and near I-R ranges. We expect to be able to localize two-pholon states via resonnant enhancement of the nonlinear cubic susceptibility and thus hopefully decpen our understinding of the origin of the nonlinearities in conjugated one-dimionsional systems.

We also expect to receive from you, al some later stage, asymmetric donor-acceptor oligomers forevaluations of boh $\beta$ andy It is of particular imponance to larify the is sue of the relative magnitudes of $\gamma$ 's for corresponding symmetric and asymmetric species and sontout the role of charae transfer stutes for $\gamma$.

Our collaboration exemplifics a case of well mutchud complementurities, skills and objectives: I need not further emphasize how priviledged we feel here to be able to investigate the fascinating optical properties of your unique molecules.

I look forward to the continuation of this frutful interaction.

Mosi sincerely yours,

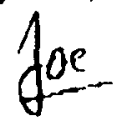

Joseph ZYYSS

Head of the Moleculur Quantum Electronics Department 